\section{Drought Resistance of Warm-season Turfgrasses Grown in Mediterranean Region of Turkey}

\author{
Songul Severmutlu ${ }^{1,8}$, Nedim Mutlu ${ }^{2}$, Ercan Gurbuz ${ }^{3}$, \\ Osman Gulsen ${ }^{4}$, Murat Hocagil $^{5}$, Osman Karaguzel ${ }^{1}$, \\ Tiffany Heng-Moss ${ }^{6}$, Robert C. Shearman ${ }^{7}$, and Rock E. Gaussoin ${ }^{7}$
}

ADDITIONAL INDEX WORDs. leaf firings, green shoot recovery, deficit irrigation

SUMMARY. There is a dearth of information about turfgrass drought resistance and adaptation in the Mediterranean region of Turkey. Turfgrass managers in this region need this information to help them make informed decisions regarding turfgrass selection and management. This research was conducted to assess the drought resistance of bermudagrass (Cynodon dactylon), buffalograss (Bucbloe dactyloides), bahiagrass (Paspalum notatum), seashore paspalum (Paspalum vaginatum), zoysiagrass (Zoysia japonica), centipedegrass (Evemochloa ophiuroides), and tall fescue (Lolium arundinaceum) under Mediterranean conditions of Turkey. The study was conducted at two locations, Antalya and Mersin, and was repeated in 2006 and 2007 at both locations. One year after establishment, the turfs were subjected to drought stress for $\mathbf{9 0}$ days, which was followed by resumption of irrigation for recovery of the turf. Percentage leaf firing, turfgrass quality, and percent green shoot recovery were recorded. There were inter and intraspecies differences detected for percentage leaf firing and shoot recovery. Bermudagrass, bahiagrass, and buffalograss exhibited superior drought resistance as demonstrated by lower leaf firing and better shoot recovery values when compared with other species studied. Centipedegrass and zoysiagrass demonstrated a high leaf firing and very poor shoot recovery, whereas zoysiagrass and tall fescue were unable to recover from the drought stress in the sandy soil. Results showed that 'SWI-1045' (Contessa $\left.{ }^{\circledR}\right)$ and 'SWI-1044' bermudagrass and 'Cody' buffalograss possessed superior drought resistance with acceptable turfgrass quality up to 30 days under drought stress that can be used for waterefficient turf management under the Mediterranean environment.

$\mathrm{I}$ $\mathrm{n}$ the Mediterranean region of Turkey, turfgrasses are grown under irrigation much of the year to maintain desired turfgrass quality.

We are grateful to Dr. T.P. Riordan for their critical review of the manuscript and their contribution to the study. We extend special thanks to Dr. K.M. Eskridge and Dr. Stephen D. Kachman, Department of Statistics, University of Nebraska, for their advice in statistical analysis.

This research was supported by the Scientific and Technical Research Council of Turkey under the project code TUBITAK TOVAG: 105 O 586.

${ }^{1}$ Department of Landscape Architecture, University of Akdeniz, Antalya, Turkey

${ }^{2}$ Department of Agricultural Biotechnology, University of Akdeniz, Antalya, Turkey

${ }^{3}$ Bati Akdeniz Agricultural Research Institute, Antalya, Turkey

${ }^{4}$ Department of Horticulture, Erciyes University, Kayseri, Turkey

${ }^{5}$ Alata Horticultural Research Institute, Mersin, Turkey

${ }^{6}$ Department of Entomology, University of Nebraska, Lincoln, NE 68588

${ }^{7}$ Department of Agronomy and Horticulture, University of Nebraska, Lincoln, NE 68588

${ }^{8}$ Corresponding author. E-mail: songulmutlu@akdeniz. edu.tr.
The availability of irrigation water is often limited in this region and water conservation for turfgrass management is of interest. Water requirements have been reported to vary by turfgrass species and cultivar (Fu et al., 2004; Kim and Beard, 1988; Youngner et al., 1981) and within cultivars of the same species (Beard and Sifers, 1997; Beard et al., 1992; Kopec et al., 1988; Shearman, 1986, 1989), with warm-season grasses typically being better able to withstand greater water deficits compared with cool-season grasses (Meyer and Gibeault, 1986; Qian and Engelke, 1999). Growing warm-season turfgrasses in arid and semiarid regions may provide better turf quality and more water savings than using cool-season turfgrasses (Beard, 1989; Brian et al., 1981; Tovey et al., 1969; Youngner et al., 1981). Short and Colmer (2007) demonstrated the opportunity for water conservation when warm-season turfgrass species were used under Mediterranean-like climate in Australia, but data on drought resistance and water conservation are lacking for the Mediterranean region.

Bermudagrass, buffalograss, bahiagrass, centipedegrass, seashore paspalum, and zoysiagrass are warmseason turfgrass species with varying drought resistance (Beard, 1973). Drought in turfgrass is manifested by leaf wilting, leaf firing, slow shoot growth, and loss of turf quality (Fry and Huang, 2004). Leaf firing provides a good assessment of overall turfgrass drought resistance under field conditions when the drought stress treatment begins with the soil at field capacity throughout the root zone (Beard and Sifers, 1997; Carrow, 1996). Leaf firing refers to leaf chlorosis and necrosis starting at leaf tips and margins, and progressing down the leaf in response to progressive drought stress. The turf recovery is considered as an indication of drought resistance under the conditions and duration of the drought stress (Beard and Sifers, 1997). Significant differences in leaf firing and shoot recovery were reported among 11 warm-season turfgrass species during and after the period of induced drought where all cool-season species showed fair to very poor drought resistance (Beard, 1989). Delayed onset of leaf firing and the accompanying decline in turfgrass quality would reduce the amount of irrigation required to maintain canopy color. Our study was conducted to assess the drought resistance and recovery, and turfgrass quality and adaptation of bermudagrass, buffalograss, bahiagrass,

\begin{tabular}{llll}
\hline $\begin{array}{l}\text { Units } \\
\text { To convert U.S. to SI, } \\
\text { multiply by }\end{array}$ & U.S. unit & SI unit & $\begin{array}{l}\text { To convert SI to U.S., } \\
\text { multiply by }\end{array}$ \\
\hline 0.3048 & $\mathrm{ft}$ & $\mathrm{m}$ & 3.2808 \\
2.54 & inch $(\mathrm{es})$ & $\mathrm{cm}$ & 0.3937 \\
25.4 & inch $(\mathrm{es})$ & $\mathrm{mm}$ & 0.0394 \\
1 & $\mathrm{mmho} / \mathrm{cm}$ & $\mathrm{dS} \cdot \mathrm{m}^{-1}$ & 1 \\
0.4470 & $\mathrm{mph}$ & $\mathrm{m} \cdot \mathrm{s}^{-1}$ & 2.2369 \\
305.1517 & $\mathrm{oz} / \mathrm{ft}^{2}$ & $\mathrm{~g} \cdot \mathrm{m}^{-2}$ & 0.0033 \\
1 & $\mathrm{ppm}$ & $\mathrm{mg} \cdot \mathrm{kg}^{-1}$ & 1 \\
$\left({ }^{\circ} \mathrm{F}-32\right) \div 1.8$ & ${ }^{\circ} \mathrm{F}$ & ${ }^{\circ} \mathrm{C}$ & $\left(1.8 \times{ }^{\circ} \mathrm{C}\right)+32$
\end{tabular}


seashore paspalum, zoysiagrass, centipedegrass, and tall fescue under Mediterranean conditions of southern Turkey.

\section{Materials and methods}

Location. The study was conducted at two locations in Turkey, the West Mediterranean Agricultural Research Institute in Antalya (lat. $36^{\circ} 52^{\prime} \mathrm{N}$, long. $30^{\circ} 43^{\prime} \mathrm{E}$ ) and the Alata Horticultural Research Institute in Mersin (lat. $36^{\circ} 37^{\prime} \mathrm{N}$, long. $\left.34^{\circ} 42^{\prime} \mathrm{E}\right)$. The locations differed strongly for their soil type, sandy vs. silty clay loam. The climate is Mediterranean with a strong marine influence (warm, dry summers and cooler, but mild winters). Mean maximum air temperatures, mean relative humidity, mean wind speed, and mean precipitation covering time of study are presented in Table 1 for both Antalya and Mersin locations. Soil on the Antalya site was a silty clay loam (Paralithic Xerortent) with a $1.4 \%$ organic matter $(\mathrm{OM})$ content, EC of $0.24 \mathrm{dS} \cdot \mathrm{m}^{-1}, \mathrm{pH} 8.4,22 \mathrm{mg} \cdot \mathrm{kg}^{-1}$ phosphorus $(\mathrm{P})$, and $117 \mathrm{mg} \cdot \mathrm{kg}^{-1}$ potassium (K). The Mersin site was a sandy soil (Typic Xerofluvent) with a $1.2 \% \mathrm{OM}$, EC of $0.17 \mathrm{dS} \cdot \mathrm{m}^{-1}, \mathrm{pH}$ $8.3,12 \mathrm{mg} \cdot \mathrm{kg}^{-1} \mathrm{P}$, and $102 \mathrm{mg} \cdot \mathrm{kg}^{-1} \mathrm{~K}$.

Plant Materials, establishment AND MAINTENANCE. Warm-season turfgrass species included bermudagrass cultivars Riviera, Sultan, Princess 77, Mohawk, NuMex Sahara, SWI-1044, SWI-1045, and Blackjack; zoysiagrass cultivars Zenith and Companion; buffalograss cultivars SWI-2000,
Bowie, Cody, Texoka, and Bison; bahiagrass cultivar Argentine; seashore paspalum cultivar Sea Spray; and centipedegrass cultivar Tifblair. Tall fescue cultivar Eldorado was used as the cool-season species.

The species were seeded at the following rates; bermudagrass and buffalograss at $15 \mathrm{~g} \cdot \mathrm{m}^{-2}$, centipedegrass and seashore paspalum at 5 $\mathrm{g} \cdot \mathrm{m}^{-2}$, zoysiagrass at $10 \mathrm{~g} \cdot \mathrm{m}^{-2}$, bahiagrass at $30 \mathrm{~g} \cdot \mathrm{m}^{-2}$, and tall fescue at $50 \mathrm{~g} \cdot \mathrm{m}^{-2}$. The seeding dates for the warm-season grasses were 15 July and 12 Aug. 2005 for the Mersin and Antalya locations, respectively. Tall fescue was seeded on 15 Oct. at both locations. The soils in experimental sites were raked and then rolled after seeding to improve seed-to-soil contact. Irrigation was provided three times daily for 4 weeks at $7 \mathrm{~mm}$ per day to encourage germination and enhance establishment. Subsequently, turf was irrigated to prevent visual wilt symptoms. Starter fertilizer $(15 \mathrm{~N}-$ $6.6 \mathrm{P}-12.5 \mathrm{~K})$ was applied at $5 \mathrm{~g} \cdot \mathrm{m}^{-2}$ $\mathrm{N}$ at time of seeding. After establishment, turfs received $17.5 \mathrm{~g} \cdot \mathrm{m}^{-2} \mathrm{~N}$ per growing season with applications made as $5 \mathrm{~g} \cdot \mathrm{m}^{-2} \mathrm{~N}$ in May, June, and July, and $2.5 \mathrm{~g} \cdot \mathrm{m}^{-2} \mathrm{~N}$ in August using a slow release $(33 \mathrm{~N}-0 \mathrm{P}-0 \mathrm{~K})$ fertilizer at both locations. In addition, 17.5 $\mathrm{g} \cdot \mathrm{m}^{-2} \mathrm{~K}$ per season was applied along with the $\mathrm{N}$ for the Mersin location. For tall fescue, applications were made as $5 \mathrm{~g} \cdot \mathrm{m}^{-2} \mathrm{~N}$ in May, $2.5 \mathrm{~g} \cdot \mathrm{m}^{-2} \mathrm{~N}$ in June, and $5 \mathrm{~g} \cdot \mathrm{m}^{-2} \mathrm{~N}$ in October and November. Soil samples were collected in Apr. 2006 and 2007 before fertilizer applications. Analysis and soil tests indicated $\mathrm{P}\left(4 \mathrm{l}\right.$ and $38 \mathrm{mg} \cdot \mathrm{kg}^{-1}$, respectively) and $\mathrm{K}$ (102 and 108 $\mathrm{mg} \cdot \mathrm{kg}^{-1}$, respectively) levels in Antalya, and $\mathrm{P}$ (12 and $28 \mathrm{mg} \cdot \mathrm{kg}^{-1}$, respectively) levels in Mersin were sufficient; while, $\mathrm{K}$ (44 and $81 \mathrm{mg} \cdot \mathrm{kg}^{-1}$, respectively) levels in Mersin were not sufficient. Plots were hand-weeded in both locations. Turfs were mowed weekly at $50 \mathrm{~mm}$ with clippings removed.

AsSESSMENT OF DROUGHT RESISTANCE. Soil water content was determined, as a composite sample from three randomly chosen plots for each block, at initiation of drought stress, at $45 \mathrm{~d}$ of drought stress, and at 90 $\mathrm{d}$ of drought stress period to determine spatial water content at 20,40, and $60 \mathrm{~cm}$ depths. Soil samples were oven dried at $72{ }^{\circ} \mathrm{C}$ for $48 \mathrm{~h}$. Volumetric moisture content (VMC) in the top $20 \mathrm{~cm}$ of soil from each plot was measured using time domain reflectometry (Spectrum Technologies, East Plainfield, IL). Turfgrass quality, percentage leaf firing (during drought stress), and recovery (after drought stress) were rated visually at 3-d intervals from the beginning of drought stress treatment until dormancy in the fall. Turfgrass quality ratings were based on a visual rating scale of 1 to 9 with $\mathrm{l}=$ poorest, $6=$ acceptable, and $9=$ best. Leaf firing was assessed using a scale of $0 \%$ to $100 \%$ with $0=$ no symptoms and $100=$ complete leaf firing, as was previously reported by Beard and Sifers (1997). Turf recovery was assessed as the percentage of green shoot development for

Table 1. Meteorological parameters during the study period in 2006 and 2007 from weather stations located $\approx 1200$ and $200 \mathrm{~m}$ (3937.0 and 656.2 ft) from the field sites in Antalya and Mersin, Turkey, respectively.

\begin{tabular}{|c|c|c|c|c|c|c|c|c|c|}
\hline \multirow[b]{2}{*}{ Location } & \multirow[b]{2}{*}{ Month } & \multicolumn{2}{|c|}{$\begin{array}{l}\text { Mean maximum } \\
\text { air temp }\left({ }^{\circ} \mathbf{C}\right)^{\mathrm{z}}\end{array}$} & \multicolumn{2}{|c|}{$\begin{array}{l}\text { Mean relative } \\
\text { humidity (\%) }\end{array}$} & \multicolumn{2}{|c|}{$\begin{array}{c}\text { Mean wind } \\
\text { speed }\left(\mathrm{m} \cdot \mathrm{s}^{-1}\right)^{\mathrm{z}} \\
\end{array}$} & \multicolumn{2}{|c|}{$\begin{array}{l}\text { Mean precipitation } \\
(\mathrm{mm})^{\mathrm{z}}\end{array}$} \\
\hline & & 2006 & 2007 & 2006 & 2007 & 2006 & 2007 & 2006 & 2007 \\
\hline \multirow[t]{6}{*}{ Antalya } & June & 38.2 & 43.5 & 57.9 & 55.7 & 4.1 & 2.1 & 0.7 & 1.4 \\
\hline & July & 40.0 & 43.8 & 55.6 & 54.2 & 2.3 & 2.0 & 0.3 & 0.2 \\
\hline & August & 42.4 & 40.5 & 66.9 & 68.1 & 1.8 & 1.9 & 3.4 & 1.0 \\
\hline & September & 38.4 & 40.3 & 60.8 & 56.2 & 2.5 & 2.0 & 1.4 & 0.0 \\
\hline & October & 33.4 & 35.6 & 68.5 & 55.2 & 2.2 & 2.0 & 494.7 & 16.6 \\
\hline & November & 26.0 & 24.4 & 60.7 & 68.2 & 2.2 & 1.7 & 126.4 & 58.2 \\
\hline \multirow[t]{6}{*}{ Mersin } & June & 28.8 & 36.1 & 65.6 & 57.6 & 1.7 & 1.7 & 3.4 & 0.0 \\
\hline & July & 31.3 & 38.2 & 60.2 & 57.5 & 1.7 & 1.7 & 0.7 & 0.6 \\
\hline & August & 32.3 & 33.8 & 66.1 & 61.9 & 1.6 & 1.8 & 0.0 & 0.0 \\
\hline & September & 30.7 & 34.0 & 54.4 & 54.2 & 1.5 & 1.6 & 13.6 & 0.0 \\
\hline & October & 26.4 & 35.3 & 63.4 & 54.5 & 1.4 & 1.4 & 68.2 & 75.9 \\
\hline & November & 20.5 & 28.5 & 51.6 & 53.8 & 1.4 & 1.5 & 202.8 & 78.2 \\
\hline
\end{tabular}

${ }^{2}\left(1.8 \times{ }^{\circ} \mathrm{C}\right)+32={ }^{\circ} \mathrm{F}, 1 \mathrm{~m} \cdot \mathrm{s}^{-1}=2.2369 \mathrm{mph}, \mathrm{l} \mathrm{mm}=0.0394$ inch. 
60-d postdrought stress period. Turfgrass green cover (turf recovery) was rated using a visual scale of $0 \%$ to $100 \%$ with $0 \%=$ no green vegetation and $100 \%=$ green vegetation over the entire plot.

The studies were conducted to evaluate drought stress resistance and recovery from drought stress. Plots were watered twice weekly to promote healthy turf growth until ceasing the irrigation upon initiation of the drought stress period, which was $90 \mathrm{~d}$ from 15 June to 15 Sept. for each year and each location. At the beginning of each drought stress treatment, grasses were at $100 \%$ green cover and plots were watered to saturation. Percentage leaf firing and quality were recorded during drought stress. Subsequently, to assess postdrought response of the turfgrasses, the plots were saturated with water and normal watering frequency was maintained thereafter for the turf recovery phase until all the warmseason cultivars entered dormancy in the late fall. Percentage green shoot recovery and quality of the cultivars were recorded until the dormancy period, but data are presented for $60 \mathrm{~d}$ after rewatering (15 Sept. to 15 Nov.) that encompassed the period of active growth.

EXPERIMENTAL DESIGN AND STATISTICAL ANALYSES. The experimental design was a split-plot with species as the whole plot treatment in a randomized complete block, and the subplot treatment being cultivars nested in species (Federer, 1955). Species within a replicate were randomized (blocked) across the field. Cultivars were nested within species. The whole plots were $5.5 \times 12.5 \mathrm{~m}$, and subplots were $1.5 \times 1.5 \mathrm{~m}$ with a $0.3-\mathrm{m}$ bare soil alleyway between each plot. Hartley's $F_{\max }$ test (Hartley, 1950) was performed to determine homogeneity of variance between locations, Antalya and Mersin, and years, 2006 and 2007. Treatment differences were tested using analysis of variance procedures with PROC MIXED (SAS release 8.0; SAS Institute, Cary, NC). Means were separated using Fisher's protected least significant difference $(P<0.05)$ procedure.

\section{Results and discussion}

Based on the Hartley's $F_{\max }$ test (Hartley, 1950), data from 2006 and 2007 were combined, but data from the Antalya and Mersin locations could not be combined. Therefore, results from the two locations were reported separately. There were sigquality, leaf firing, and turf recovery between years and species on some evaluation dates at both locations (Table 2). The interactions were mainly caused by change in the order of species, namely bermudagrass vs. buffalograss, and centipedegrass vs. zoysiagrass on some evaluation dates between 2 years. However, trends were similar for both years and data were not reported separately.

Drought STRESS PERIOD. The leaf firing and quality assessments for the species and their cultivars are Antalya and Mersin locations. The $90 \mathrm{~d}$ drought was a severe period of dehydration stress. Experimental nificant interactions for turfgrass shown in Tables 3 and 4 for the

locations had contrasting soil types, a silty clay loam at Antalya and a highly sandy soil at Mersin. The degree of drought injury depends upon the growing medium (soil), plant, and atmospheric factors (Schmidt, 1973). Since sandy soils drain too well and dry out too quickly, during dry periods they are often incapable of supplying plants with enough water to meet the transpirational requirements (Emmons, 2000). Thus, the Mersin location presented a much harsher soil environment for drought stress. Soil water content by weight at 0-20 $\mathrm{cm}$ soil depth was $17 \%$ and $13 \%$ measured just before drought stress treatment was initiated. It declined to $3.1 \%$ and $2.2 \%$ by $90 \mathrm{~d}$ of drought stress at the Antalya and Mersin locations, respectively (Table 5). VMC values (measured with TDR) were 40.2 at Antalya and 16.3 at Mersin

Table 2. Analysis of variance for turfgrass quality and leaf firing during 90 -d drought stress, and turfgrass quality and shoot recovery after irrigation resumed at Antalya and Mersin, Turkey for combined data of 2006 and $2007 .^{\mathrm{z}}$

\begin{tabular}{|c|c|c|c|c|c|c|}
\hline \multirow[b]{2}{*}{ Location } & \multirow{2}{*}{$\begin{array}{l}\text { Source of } \\
\text { variation }\end{array}$} & \multirow[b]{2}{*}{ df } & \multicolumn{2}{|c|}{ Drought stress period } & \multicolumn{2}{|c|}{ Recovery period } \\
\hline & & & Quality & Leaf firing & Quality & Shoot recovery \\
\hline \multirow[t]{11}{*}{ Antalya } & Block (B) & 2 & $\mathrm{NS}^{\mathrm{y}}$ & $2^{x}$ & 3 & 2 \\
\hline & Species $(S)$ & 6 & 21 & 30 & 20 & 20 \\
\hline & $\begin{array}{l}\text { Whole plot } \\
\quad \text { error }(B \times S)\end{array}$ & 12 & & & & \\
\hline & Cultivar (C) & 12 & 26 & 13 & 11 & NS \\
\hline & $\begin{array}{l}\text { Split-plot error } \\
{[\mathrm{B} \times \mathrm{C}(\mathrm{S})]}\end{array}$ & 24 & & & & \\
\hline & Year $(\mathrm{Y})$ & 1 & 19 & 17 & 13 & 11 \\
\hline & $\mathrm{B} \times \mathrm{Y}$ & 2 & 4 & 3 & 3 & 2 \\
\hline & $\mathrm{Y} \times \mathrm{S}$ & 6 & 16 & 15 & 12 & 10 \\
\hline & $\mathrm{B} \times \mathrm{Y} \times \mathrm{S}$ & 12 & 7 & 9 & 6 & 5 \\
\hline & $\mathrm{Y} \times \mathrm{C}(\mathrm{S})$ & 12 & 13 & 15 & 2 & 3 \\
\hline & Residual & 30 & & & & \\
\hline \multirow[t]{11}{*}{ Mersin } & B & 2 & 1 & NS & NS & NS \\
\hline & S & 6 & 5 & 10 & 18 & 19 \\
\hline & $\mathrm{B} \times \mathrm{S}$ & 12 & & & & \\
\hline & $\mathrm{C}$ & 12 & 7 & 11 & 2 & 11 \\
\hline & $\mathrm{B} \times \mathrm{C}(\mathrm{S})$ & 24 & & & & \\
\hline & $\mathrm{Y}$ & 1 & 7 & 15 & 14 & 15 \\
\hline & $\mathrm{B} \times \mathrm{Y}$ & 2 & 3 & 8 & 7 & 8 \\
\hline & $\mathrm{Y} \times \mathrm{S}$ & 6 & 8 & 16 & 14 & 13 \\
\hline & $\mathrm{B} \times \mathrm{Y} \times \mathrm{S}$ & 12 & 3 & 7 & 5 & 5 \\
\hline & $\mathrm{Y} \times \mathrm{C}(\mathrm{S})$ & 12 & 1 & 11 & 14 & 13 \\
\hline & Residual & 30 & & & & \\
\hline
\end{tabular}

${ }^{2}$ The data belong to set of 30 weeks and weekly data were analyzed separately. The numbers indicate total number of weeks where treatment differences were significant. The species and cultivars were as follows: bermudagrass [cultivars SWI-1044, SWI-1045 (Contessa), Princess 77, Riviera, Mohawk, Sultan, NuMex Sahara, and Blackjack], buffalograss (cultivars Cody, Bowie, SWI-2000, Bison, and Texoka), zoysiagrass [cultivars Zenith and Companion (Compadre)], seashore paspalum (cultivar Sea Spray), centipedegrass (cultivar Tifblair), bahiagrass (cultivars Argentine and Pensacola), and tall fescue (cultivar Eldorado)

${ }^{\mathrm{y}_{\mathrm{NS}}}=$ Nonsignificant at $P \leq 0.05$

${ }^{x}$ Number indicates number of evaluations when treatment differences were significant at $P \leq 0.05$ out of 30 evaluations. 


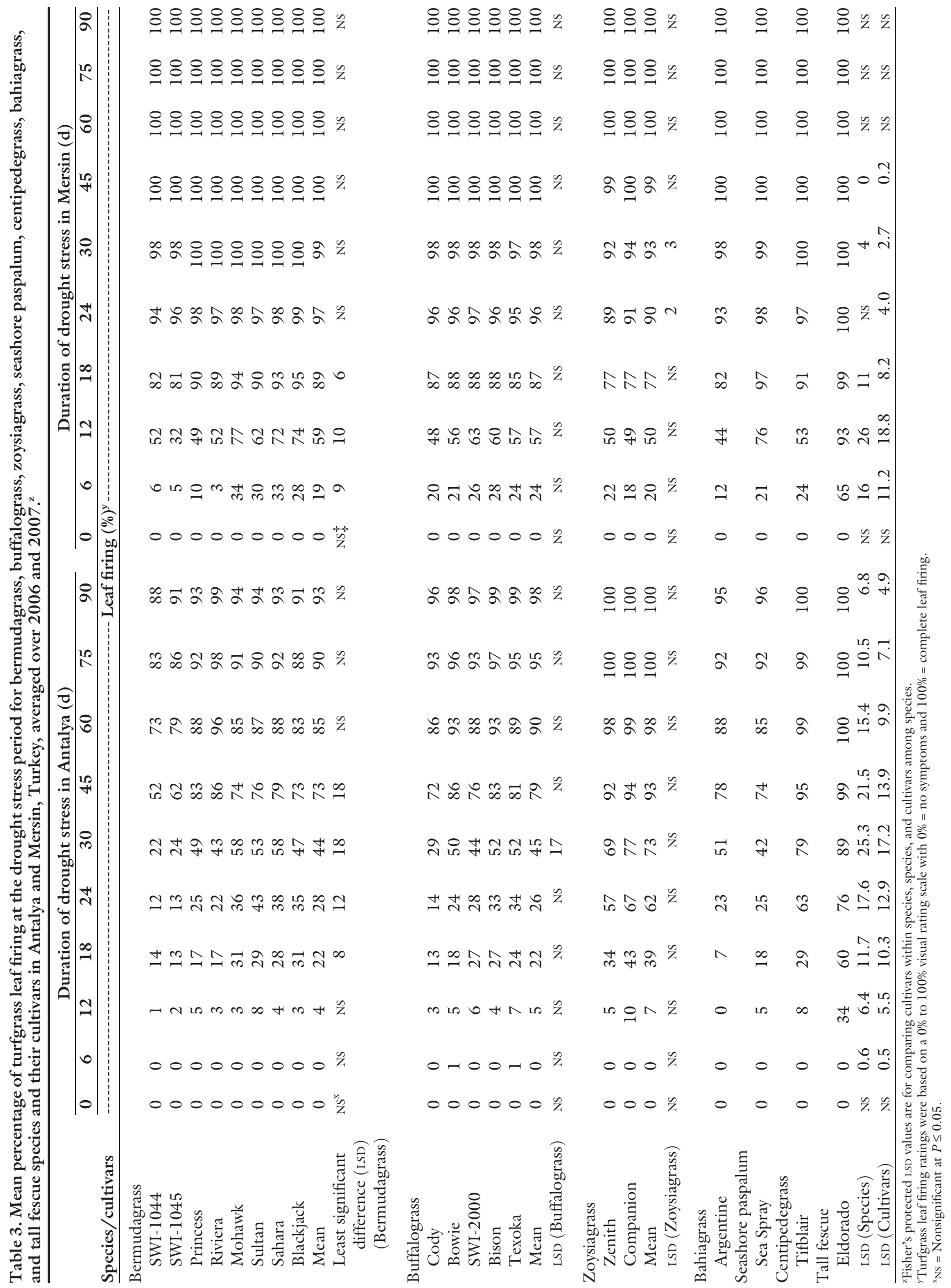




\section{Research Reports}

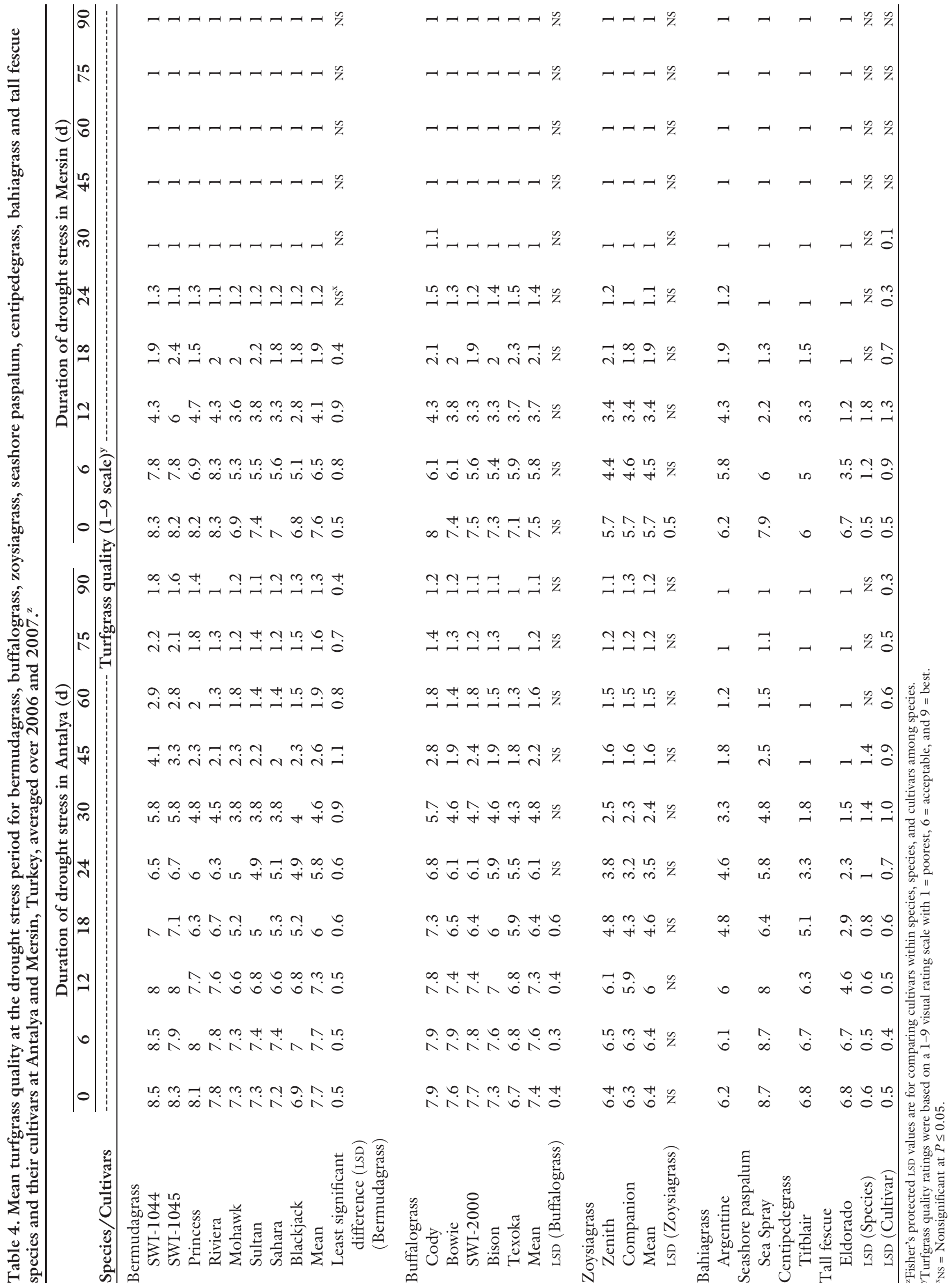


Table 5. Water content of soil samples at $0-20,20-40$, and $40-60 \mathrm{~cm}$ in depths as measured at the beginning ( 15 June), the middle ( $30 \mathrm{July}$ ), and the end (14 Sept.) of 90-d drought stress periods at Antalya and Mersin, Turkey in 2006 and 2007.

\begin{tabular}{|c|c|c|c|c|c|}
\hline \multirow[b]{4}{*}{ Date } & \multirow{4}{*}{$\begin{array}{l}\text { Soil depth } \\
\quad(\mathrm{cm})^{\mathrm{z}}\end{array}$} & \multicolumn{4}{|c|}{ Location } \\
\hline & & \multicolumn{2}{|c|}{ Antalya } & \multicolumn{2}{|c|}{ Mersin } \\
\hline & & 2006 & 2007 & 2006 & 2007 \\
\hline & & ------- & -Water & $t(\%)^{y}-$ & $-\cdots--\cdot$ \\
\hline \multirow[t]{3}{*}{15 June } & $0-20$ & 16.7 & 17.4 & 13.7 & 12.7 \\
\hline & $20-40$ & 16 & 16.6 & 11.2 & 10.6 \\
\hline & $40-60$ & 16.1 & 15.4 & 9.0 & 9.5 \\
\hline \multirow[t]{3}{*}{30 July } & $0-20$ & 3.0 & 3.3 & 3.0 & 2.7 \\
\hline & $20-40$ & 3.4 & 3.4 & 3.1 & 2.8 \\
\hline & $40-60$ & 3.8 & 4.0 & 3.1 & 3.0 \\
\hline \multirow[t]{3}{*}{14 Sept } & $0-20$ & 3.1 & 2.8 & 2.2 & 2.1 \\
\hline & $20-40$ & 3.1 & 3.0 & 2.2 & 2.0 \\
\hline & $40-60$ & 3.5 & 3.6 & 2.3 & 2.2 \\
\hline
\end{tabular}

${ }^{\mathrm{z}} 1 \mathrm{~cm}=0.3937$ inch.

y Soil samples were weighed immediately after sampling, dried in the oven at $72{ }^{\circ} \mathrm{C}\left(161.6{ }^{\circ} \mathrm{F}\right)$ for $48 \mathrm{~h}$ and the ratio is given as percent water content $[($ dry sample/wet sample $) \times 100]$.

when plots were fully watered to saturation before initiation of drought stress, compared with dry soil's values ranging from 5 to 2 at 45 and $90 \mathrm{~d}$ of drought stress at both locations, respectively. Growing degree days (GDD) values, with a base temperature of $5{ }^{\circ} \mathrm{C}$, for the $90-\mathrm{d}$ drought stress periods were 1513 and 1535 GDD for Antalya, and 1450 and 1428 for Mersin for 2006 and 2007, respectively.

Drought resistant turfgrasses are able to maintain better turfgrass quality and have less leaf firing during drought stress (Huang and Gao, 1999; Qian and Fry, 1997). Green color retention during the progressive drought stress is an important indication of drought resistance (Sifers and Beard, 1999). Mean differences in percentage leaf firing of species under $90 \mathrm{~d}$ of drought stress were significant $(P>0.05)$ on most of the evaluation dates at both locations (Table 3 ). Significant intraspecies variation in leaf firing occurred within bermudagrass early to midway through the drought stress period. Virtually no intraspecific leaf firing variation was observed for buffalograss or zoysiagrass. Interspecific variation in leaf firing was significant throughout drought stress period in Antalya, however, it was significant only for the first $18 \mathrm{~d}$ of the $90-\mathrm{d}$ drought stress period in Mersin due probably to more severe heat/drought stress. Percent leaf firing increased, and quality declined two to three times faster at Mersin than at the Antalya location (Table 3 and 4). All the warm-season species exhibited over $90 \%$ leaf firing with a straw brown color after 75 and $24 \mathrm{~d}$ of drought stress at Antalya and Mersin, respectively (Table 3 ). The big difference in days of drought stress to $90 \%$ leaf firing at the two locations was due to the highly sandy soil type in Mersin and silty loam in Antalya. Percent leaf firing was similar for bermudagrass, buffalograss, bahiagrass, and seashore paspalum at Antalya (Table 3). Among the warm-season species, centipedegrass and zoysiagrass species showed the poorest green color retention that may indicate an inferior drought resistance mechanism compared with the other warm-season species at Antalya. Bahiagrass showed lower leaf firing than other species during the first $15-21 \mathrm{~d}$ of drought stress at both locations (Table 3 ). Overall, bermudagrass, buffalograss, bahiagrass, and seashore paspalum at Antalya and bahiagrass at Mersin demonstrated better green color retention.

Although more severe at Mersin because of sandy nature of its soil, drought stress caused rapid declines in visual quality at both locations. Mean quality differences among species were significant until 60 and $18 \mathrm{~d}$ of drought stress at the Antalya and Mersin locations (Table 4). As the severity of drought stress intensified, differences in quality among the species diminished. Buffalograss, bermudagrass, and seashore paspalum consistently exhibited higher quality ratings than other species at Antalya
(Table 4). These species provided an acceptable quality until $21 \mathrm{~d}$ of drought stress at Antalya. However, all the species declined below an acceptable quality at $12 \mathrm{~d}$ of drought stress at Mersin (Table 4).

Green color retention was outstanding for bermudagrass cultivars SWI-1044 and SWI-1045, which had less than $25 \%$ leaf firing with an acceptable quality at $30 \mathrm{~d}$ of drought stress at Antalya (Tables 3 and 4). At Mersin, however, 'SWI-1045' was the only cultivar with an acceptable quality at $12 \mathrm{~d}$ of drought stress. Green color retention and quality of 'SWI-1044', 'SWI-1045', 'Princess 77 ', and 'Riviera' were superior to other bermudagrass cultivars at both locations (Table 4). Low leaf firing and high shoot recovery, low leaf area and high canopy resistance (attributed to high shoot density), horizontal leaf angle, and a slow vertical leaf elongation are important indicators for selecting cultivars with low water use rates and drought resistance (Beard, 1989). Among the bermudagrass cultivars, those high-density, low-growing new cultivars SWI1044, SWI-1045, Riviera, and Princes 77 [National Turfgrass Evaluation Program (NTEP), 2006] exhibited superior drought resistance; while those lower-density, high-growing cultivars NuMex Sahara, Mohawk, Blackjack, and Sultan showed lower drought resistance. These newer bermudagrass cultivars were also able to retain their color about twice as long as older cultivars. Newer type cultivars possess better genetic color and groundcoverage, narrower-finer leaf texture, and slower vertical growth than older cultivars (NTEP, 2006; Severmutlu et al., 2011). These morphological and physiological differences may be contributing to better color retention of new bermudagrass cultivars under drought stress. Beard and Sifers (1997) also reported significant intraspecies drought resistance differentials within bermudagrass.

Buffalograss cultivars showed significant mean differences for green color retention and quality early in the drought stress. Among the buffalograss cultivars, Cody had the best drought resistance with 29\% leaf firing after $30 \mathrm{~d}$ and $48 \%$ leaf firing after $12 \mathrm{~d}$ at Antalya and Mersin, respectively (Table 3). 'Cody' demonstrated a better turfgrass quality than other 
buffalograss cultivars at both locations, with an acceptable quality until 30 and $6 \mathrm{~d}$ of drought stress at Antalya and Mersin, respectively (Table 4). Buffalograss is relatively drought resistant and has a deep, extensive root system (Marcum et al., 1995; Qian and Fry, 1997). Buffalograss was reported to have good drought resistance because of its deep root system and summer dormancy under extremely dry conditions (Riordan et al., 1993; Qian et al., 1996). It also has been reported to have a low ET rate (Qian et al., 1996) and excellent ability to tolerate drought and then recover (Qian and Fry, 1997). Buffalograss cultivars along with bermudagrass cultivars were ranked highest for drought resistance in our study. Among the buffalograss cultivars, Cody exhibited a superior drought resistance than the other buffalograss cultivars (Table 3 ). 'Cody' was reported to have the highest drought resistance among seeded buffalograss cultivars (Morris, 1996). It possesses five times the leaf pubescence of buffalograss 'Tatanka' and has a smaller and narrower leaf than 'Texoka' (Severmutlu et al., 2005) that may lower its evapotranspiration level, giving rise to better water use efficiency. Presence of leaf pubescence was shown to reduce absorbance of photosynthetically active radiation (400 to $700 \mathrm{~nm}$ ) as much as 56\% (Ehleringer et al., 1976). This in turn may reduce oxidative stress that would otherwise damage the photosynthetic apparatus, causing a loss of color and quality of turf.

Zoysiagrass cultivars Zenith and Companion showed similar quality with complete leaf firing after 90 and $30 \mathrm{~d}$ of drought stress at the Antalya and Mersin locations, respectively (Tables 3 and 4). Zoysiagrass is considered to be more drought resistant than cool-season turfgrasses and intermediate to other warmseason grasses (Hatch and White, 2004). The evapotranspiration rates of zoysiagrass cultivars and germplasm were similar under nonlimiting water availability (Green et al., 1991) but differed markedly in response to drought (White et al., 1993, 2001). When all cultivars were evaluated together, irrespective of species, mean differences of percent leaf firing among cultivars were significant at all evaluation dates. After $15 \mathrm{~d}$ of drought stress, tall fescue 'Eldorado'
(46\%), zoysiagrass ‘Companion’ (23\%), and bermudagrass 'Blackjack' (21\%) exceeded $20 \%$ leaf firing while buffalograss 'Cody' and bahiagrass 'Argentine' were below 5\% at Antalya while all the cultivars had over $60 \%$ leaf firing at this time at Mersin(data not shown). However, at $12 \mathrm{~d}$ of drought stress, 'SWI-1045' bermudagrass was the only cultivar with an acceptable quality (6) at Mersin (Table 4). 'SWI-1044' and 'SWI-1045' bermudagrass and 'Cody' buffalograss showed the lowest leaf firing and the highest quality (Tables 3 and 4).

RECOVERY AFTER DROUGHT STRESS. GDD values for 60-d postdrought stress period were 907 and 1086 for Antalya, and 934 and 1007 for Mersin locations in 2006 and 2007 , respectively. Mean differences for green shoot recovery of the turf after rewatering of turf plots, among species were significant $(P<0.05)$ throughout the $60 \mathrm{~d}$ of recovery (DOR) period from 15 Sept. to 15 Nov. (Table 6). There were no significant intraspecies differences for shoot recovery among bermudagrass, buffalograss, and zoysiagrass cultivars (Table 6). Bermudagrass, buffalograss, and bahiagrass demonstrated superior shoot recovery and regained their quality faster than other species after rewatering (Tables 6 and 7). Although bahiagrass recovered quicker, seashore paspalum was able to recover equally as well after 60 DOR at both locations (Table 6). Zoysiagrass, centipedegrass, and tall fescue showed the lowest shoot recovery and failed to recover in Mersin. They stayed below 26\% green shoot cover at Antalya after 45 DOR, while all the other species recovered over $30 \%$ at Mersin and $80 \%$ at Antalya (Table 6). The mean quality of bermudagrass exceeded the acceptable level after 30 DOR and buffalograss at 33 DOR at Antalya. All the bermudagrass and buffalograss cultivars reached the acceptable quality at Antalya after 45 DOR period (Table 7). Although there were differences on some evaluation dates, species may be ordered for shoot recovery, from high to low, as follows: bermudagrass = buffalograss $\geq$ bahiagrass $\geq$ seashore paspalum $>$ centipedegrass $>$ zoysiagrass $>$ tall fescue.

Drought resistance was outstanding for all of the bermudagrass cultivars, as demonstrated by the degree of green shoot recovery of the turf during the $60 \mathrm{~d}$ following rewatering of the plots (Table 6). 'SWI-1044' at Antalya and 'Riviera' at Mersin recovered better and regained their quality faster than the other bermudagrass cultivars (Tables 6 and 7). 'SWI-1044' bermudagrass was above the acceptable quality level at 21 DOR in Antalya (Table 7). After $30 \mathrm{~d}$ of rewatering, green shoot cover varied from $82 \%$ ('Princess 77') to 92\% ('SWI-1044') at Antalya and from $28 \%$ ('Blackjack') to $43 \%$ ('Riviera') at Mersin. However, all the bermudagrass cultivars exhibited more than $90 \%$ shoot recovery at Antalya and $35 \%$ at Mersin at $45 \mathrm{~d}$ of rewatering (Table 6). After 54 DOR, only 'SWI1044 ' was $100 \%$ fully green at Antalya and 'Riviera' exhibited the highest green cover with $67 \%$ at Mersin (Table 6). While 'Riviera' recovered better in the sandy soil, 'Blackjack' was significantly slow, indicating a lower drought resistance of 'Blackjack' in sandy soils (Table 6).

Shoot recovery of all the buffalograss cultivars was outstanding and was similar to bermudagrass cultivars. All the buffalograss cultivars exhibited over $87 \%$ and $36 \%$ green shoot recovery after $45 \mathrm{DOR}$ at Antalya and Mersin, respectively (Table 6). At Antalya, all buffalograss cultivars had equal or above acceptable quality at $45 \mathrm{~d}$. However, none of the cultivars reached acceptable quality during the recovery period at Mersin. Overall, shoot recovery results indicated that 'Cody' showed superior drought resistance and quality at both locations (Table 7). At 21 DOR, 'Cody' exceeded the acceptable quality level at Antalya (Table 7).

Both zoysiagrass cultivars Zenith and Companion demonstrated poor recovery and quality (Tables 6 and 7). Green shoot recovery $45 \mathrm{~d}$ of rewatering was very slow with around $15 \%$ at Antalya and $1 \%$ at Mersin (Table 6). Zoysiagrass and centipedegrass were the first two warm-season species to lose green color under drought stress and were the least responsive to rewatering, indicating poor drought resistance of these species. Using warm-season grasses, Beard (1989) also observed that those species that turned yellow or brown earlier tend to have poorer postdrought stress shoot recovery or poor drought resistance. Centipedegrass and zoysiagrass 
Table 6. Mean percentage of turfgrass shoot recovery at the postdrought stress recuperation period for bermudagrass, buffalograss, zoysiagrass, seashore paspalum, centipedegrass, bahiagrass and tall fescue species and their cultivars at Antalya and Mersin, Turkey, averaged over 2006 and $2007 .{ }^{\mathrm{z}}$

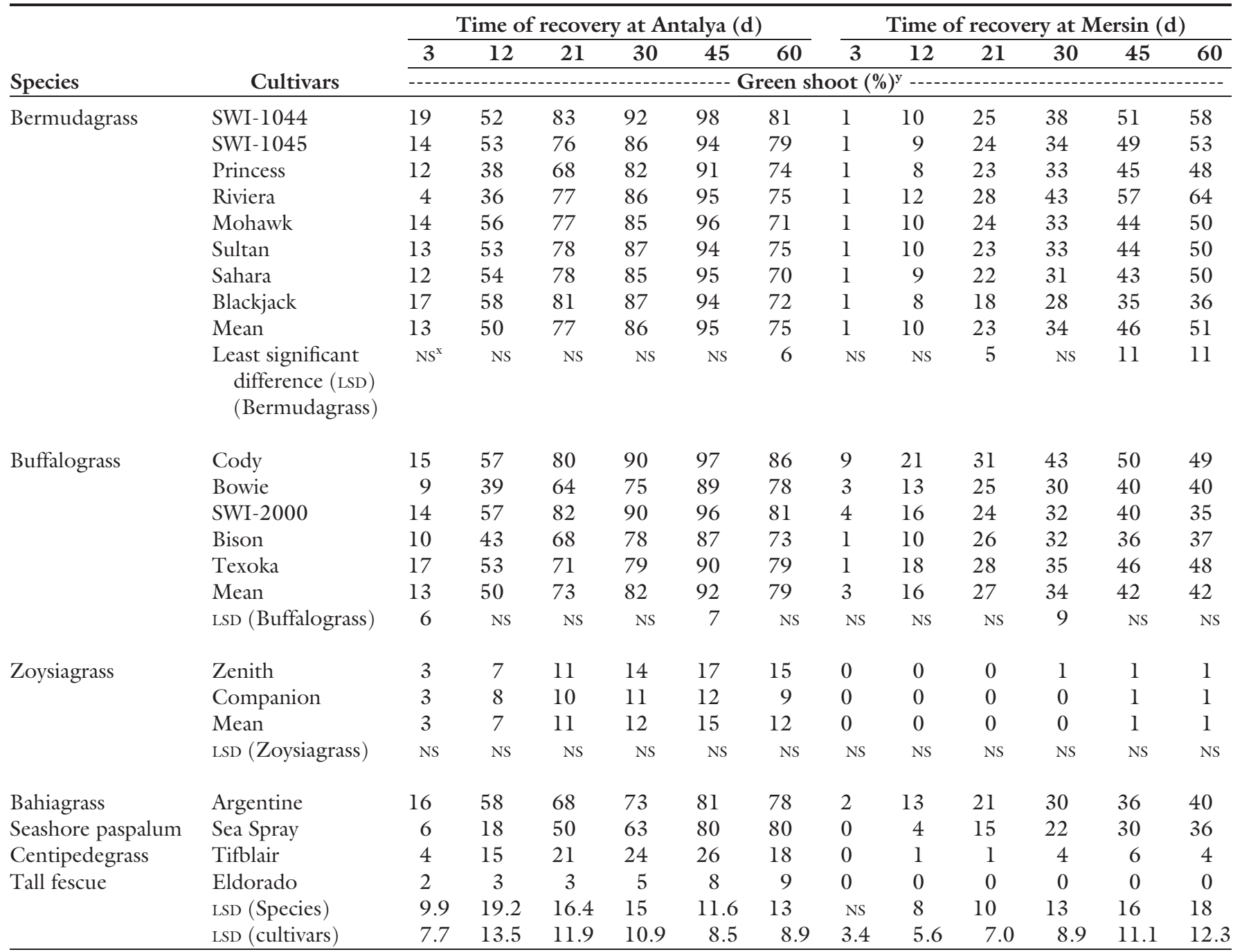

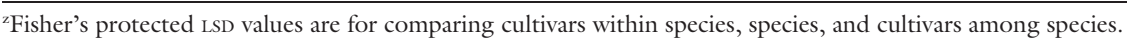

y Turfgrass shoot recovery ratings were based on a $0 \%$ to $100 \%$ visual rating scale with $0 \%=$ no green shoot development and $100 \%=$ full green shoot development. ${ }^{\mathrm{x}} \mathrm{NS}=$ Nonsignificant at $P \leq 0.05$.

concentrate their root mass closer to the soil surface compared with bermudagrass, buffalograss, and bahiagrass (Green et al., 1991). This physiological difference may explain the shorter green color retention (and higher leaf firing) of zoysiagrass and centipedegrass than bermudagrass, buffalograss, and bahiagrass that was observed in this study. Qian and Fry (1997) reported that buffalograss exhibited superior drought resistance compared with zoysiagrass when the entire soil profile was subjected to drought stress. The difference between bermudagrass, buffalograss, bahiagrass vs. zoysiagrass and centipedegrass in drought resistance could be associated with differences in root elongation rate, root distribution patterns, and the capacity to absorb water and nutrients. Under drying conditions, field and greenhouse experiments showed that buffalograss roots elongated faster than zoysiagrass roots, which could contribute to deeper root systems in buffalograss that had a larger proportion of its roots deep in the soil (Huang, 1999; Qian and Fry, 1997). Carrow (1996) also reported that zoysiagrass produced few roots and had low root length density below $20 \mathrm{~cm}$. Zoysiagrass used water near the surface because of the presence of extensive roots in the surface soil, whereas the development of roots in the deeper soil layers by buffalograss enhanced water uptake from deep in the soil profiles (Huang, 1999). Water efflux (hydraulic lift), where deep roots act as a water transport system that retrieves water from deep in the profile and delivers it to the drying surface soil at night, has been reported in bermudagrass [Cynodon dactylon $\times C$. transvaalensis (Baker and Van Bavel, 1986)] and buffalograss (Huang, 1999). This "hydraulic lift" in the soil profile helps to support root growth and functions in nutrient uptake in the upper soil profile, which can lead to efficient use of water under surface soil drying conditions resulting in delaying drought stress injury (Huang, 1999). Superior green color retention of bermudagrass and buffalograss at Antalya may be explained by "hydraulic lift." However, the highly sandy nature of the soil in Mersin may have 
Table 7. Mean turfgrass quality at the postdrought stress recuperation period for bermudagrass, buffalograss, zoysiagrass, seashore paspalum, centipedegrass, bahiagrass and tall fescue species and their cultivars at Antalya and Mersin, Turkey, averaged over 2006 and $2007 .^{\mathrm{z}}$

\begin{tabular}{|c|c|c|c|c|c|c|c|c|c|c|c|c|c|}
\hline \multirow[b]{3}{*}{ Species } & \multirow[b]{3}{*}{ Cultivars } & \multicolumn{6}{|c|}{ Time of recovery at Antalya (d) } & \multicolumn{6}{|c|}{ Time of recovery at Mersin $(\mathrm{d})$} \\
\hline & & 3 & 12 & 21 & 30 & 45 & 60 & 3 & 12 & 21 & 30 & 45 & 60 \\
\hline & & \multicolumn{12}{|c|}{ - } \\
\hline & SWI-1045 & 1.7 & 3.7 & 5.9 & 6.8 & 7.5 & 6.1 & 1.2 & 1.5 & 2.5 & 3.3 & 4 & 4 \\
\hline & Princess & 1.4 & 2.7 & 5.1 & 6.4 & 7.2 & 5.9 & 1.1 & 1.5 & 2.3 & 3.2 & 4.2 & 3.9 \\
\hline & Riviera & 1 & 2.5 & 5.8 & 6.7 & 7.3 & 5.8 & 1 & 1.8 & 3 & 3.8 & 5 & 4.6 \\
\hline & Sahara & 1.3 & 3 & 5.3 & 5.7 & 5.9 & 4.9 & 1.1 & 1.5 & 2.3 & 3.1 & 4.2 & 4.3 \\
\hline & Blackjack & 1.5 & 3.3 & 5.4 & 5.7 & 6 & 5.2 & 1.1 & 1.3 & 2.1 & 2.7 & 3.3 & 3.2 \\
\hline & Mean & 1.4 & 3.2 & 5.5 & 6.3 & 6.8 & 5.5 & 1.1 & 1.6 & 2.4 & 3.2 & 4.1 & 4.1 \\
\hline & $\begin{array}{l}\text { Least significant } \\
\text { difference (LSD) } \\
\text { (Bermudagrass) }\end{array}$ & 0.6 & 1 & 1.3 & 1 & 0.7 & 0.4 & NSt & 0.4 & 0.5 & 0.6 & 0.7 & 0.8 \\
\hline & SWI-2000 & 1.6 & 3.8 & 5.9 & 6.5 & 6.8 & 5.5 & 1.2 & 1.9 & 2.3 & 2.7 & 3.3 & 2.8 \\
\hline & Bison & 1.4 & 3.2 & 4.7 & 5.5 & 6.1 & 4.9 & 1 & 1.6 & 2.2 & 2.7 & 3.3 & 3.1 \\
\hline & Texoka & 1.6 & 3.5 & 4.9 & 5.4 & 6 & 5 & 1 & 2.3 & 2.5 & 3 & 3.5 & 3.5 \\
\hline & Mean & 1.5 & 3.4 & 5.3 & 5.9 & 6.4 & 5.2 & 1.1 & 1.8 & 2.4 & 2.9 & 3.5 & 3.2 \\
\hline & LSD (Buffalograss) & $\mathrm{NS}^{\mathrm{x}}$ & 1 & NS & NS & NS & NS & NS & NS & NS & NS & NS & NS \\
\hline \multirow[t]{4}{*}{ Zoysiagrass } & Zenith & 1.1 & 1.3 & 1.4 & 1.6 & 1.7 & 1.6 & 1 & 1 & 1 & 1 & 1 & 1 \\
\hline & Companion & 1.3 & 1.3 & 1.4 & 1.4 & 1.3 & 1.1 & 1 & 1 & 1 & 1 & 1 & 1 \\
\hline & Mean & 1.2 & 1.3 & 1.4 & 1.5 & 1.5 & 1.4 & 1 & 1 & 1 & 1 & 1 & 1 \\
\hline & LSD (Zoysiagrass) & NS & NS & NS & NS & NS & NS & NS & NS & NS & NS & NS & NS \\
\hline
\end{tabular}

${ }^{2}$ Fisher's protected LSD values are for comparing cultivars within species, species, and cultivars among species.

'Turfgrass quality ratings were based on a $1-9$ visual rating scale with $1=$ poorest, $6=$ acceptable, and $9=$ best. ${ }^{x_{N S}}=$ Nonsignificant at $P \leq 0.05$.

prevented this phenomenon, causing significantly faster color loss and more severe leaf firing than at Antalya.

Although 'Argentine' bahiagrass demonstrated less leaf firing than 'Sea Spray' seashore paspalum, both showed similar shoot recovery. Dehydration avoidance and deep rooting, but not reduced evapotranspiration, were suggested to be likely mechanisms for drought resistance of bahiagrass (Busey, 2003). Bahiagrass was reported to have $82 \%$ (Doss et al., 1960 ) and $46 \%$ higher root dry weight than common bermudagrass (Burton et al., 1954). Superior rooting may explain low leaf firing and high shoot recovery of 'Argentine' bahiagrass observed in both locations. It is best adapted to sandy soils (Gates et al.,
2004), which may explain relatively less leaf firing and better shoot recovery of bahiagrass observed in the sandy soil type at the Mersin location. Bahiagrass also can survive well on droughty soils and compensates for low moisture availability with a more open stand (Gates et al., 2004). Stand density of 'Argentine' bahiagrass and 'Sea Spray' seashore paspalum declined overall in the plots under prolonged drought stress. The two species may have a similar mechanism in trying to cope with water scarcity by thinning the stand and supporting the remaining green shoots with the available water.

When all cultivars were evaluated altogether regardless of species, mean differences in shoot recovery among cultivars were significant $(P<0.05)$ on most of the evaluation dates. Bermudagrass cultivars SWI-1044, SWI-1045, and Riviera, and 'Cody' buffalograss exhibited the highest shoot recovery. At 30 DOR, 'SWI1044'bermudagrass, and 'SWI-2000' and 'Cody' buffalograss recovered over $90 \%$ at Antalya and 'Cody' buffalograss and 'Riviera' bermudagrass over $40 \%$ at Mersin (Table 6). Percent shoot recovery of zoysiagrass cultivars was $15 \%$ and $1 \%$, centipedegrass was $26 \%$ and $6 \%$, and tall fescue was $8 \%$ and $0 \%$ at Antalya and Mersin, respectively (Table 6). The results show that the species/cultivars exhibit marked differences in drought resistance.

Understanding drought resistant species and cultivars will facilitate the development of better water-use 
efficient management practices for areas with limited water resources by growing the most drought resistant species and cultivars with acceptable quality. Results show that 'SWI1044' and 'SWI-1045' bermudagrass and 'Cody' buffalograss possess superior drought resistance with higher turfgrass quality, which can be used for water-efficient turf management under the Mediterranean environment. The cultivars that maintained acceptable turfgrass quality with less than $30 \%$ leaf firing until $30 \mathrm{~d}$ of drought stress indicate potential water savings to turf managers in this environment. Moreover, since the mean leaf firing for all warm-season species was below $20 \%$ at 15 d of drought stress at Antalya, deficit irrigation may be applied to the warmseason species without significantly reducing the turfgrass quality. The fact that reduction in the quality of warm-season grasses was within acceptable range up to $15 \mathrm{~d}$ of drought stress also suggests that many turfs are over watered in the region.

In conclusion, bermudagrass and buffalograss species/cultivars may perform better than other warm-season species and cool-season species that are commonly used in this region and provide quality turf with reduced water-use requirements. These results will be helpful to turfgrass managers seeking to manage and recommend suitable warm-season turfgrass species and cultivars for water conservation for the Mediterranean region. These results may also help expand the use of some of these cultivars under water deficit conditions in Mediterraneanlike climates throughout the world.

\section{Literature cited}

Baker, J.M. and C.H.M. Van Bavel. 1986. Resistance of plant roots to water loss. Agron. J. 78:641-644.

Beard, J.B. 1973. Turfgrass: Science and culture. Prentice-Hall, Englewood Cliffs, NJ.

Beard, J.B. 1989. Turfgrass water stress: Drought resistance components, physiological mechanisms, and species-genotype diversity, p. 23-28. In: H. Takatoh (ed.). Proc. 6th Intl. Turf Res. Conf. Jpn. Soc. Turfgrass Sci., Tokyo.

Beard, J.B., R.L. Green, and S.I. Sifers. 1992. Evapotranspiration and leaf extension rates of 24 well-watered, turf-type
Cynodon genotypes. HortScience 27:986-988.

Beard, J.B. and S.I. Sifers. 1997. Genetic diversity in dehydration avoidance and drought resistance within the Cynodon and Zoysia species. Intl. Turfgrass Soc. Res. J. 8:603-610.

Brian, I., B. Bravdo, I. Bushkin-Harav, and E. Rawitz. 1981. Water consumption and growth rate of 11 turfgrasses as affected by mowing height, irrigation frequency, soil moisture. Agron. J. 73:85-90.

Burton, G.W., E.H. DeVane, and R.L. Carter. 1954. Root penetration, distribution and activity in southern grasses measured by yields, drought symptoms, and P32 uptake. Agron. J. 46:229-233.

Busey, P. 2003. Bahiagrass, paspalum notatum Flügge, p. 331-348. In: M.D. Casler and R.R. Duncan (eds.). Turfgrass biology, genetics, and breeding. Wiley, Hoboken, NJ.

Carrow, R.N. 1996. Drought resistance aspects of turfgrasses in the southeast: Root-shoot responses. Crop Sci. 36:687694.

Doss, B.D., D.A. Ashley, and O.L. Bennett. 1960. Effect of soil moisture regime on rooting distribution of warm-season forage species. Agron. J. 52:569-572.

Ehleringer, J., O. Björkman, and H.A. Mooney. 1976. Leaf pubescence: Effects on absorptance and photosynthesis in a desert shrub. Science 192:376-377.

Emmons, R. 2000. Turfgrass science and management. Delmar, Albany, NY.

Federer, W.T. 1955. Experimental design: Theory and application. Macmillan, New York.

Fry, J. and B. Huang. 2004. Applied turfgrass science and physiology. Wiley, Hoboken, NJ.

Fu, J.M., J. Fry, and B.R. Huang. 2004. Minimum water requirements of four turfgrasses in the transition zone. HortScience 39:1740-1744.

Gates, R.N., C.L. Quarin, and C.G.S. Pedreira. 2004. Bahiagrass, p. 651-680. In: L.E. Moser, B.L. Burson, and L.E. Sollenberger (eds.). Warm-season (C4) grasses. Monogr. No. 45. Amer. Soc. Agron., Crop Sci. Soc. Amer., Soil Sci. Soc. Amer., Madison, WI.

Green, R.L., J.B. Beard, and M.J. Oprisko. 1991. Root hairs and root lengths in 9 warm-season turfgrass genotypes. J. Amer. Soc. Hort. Sci. 1 16:965-969.

Hartley, H.O. 1950. The maximum Fratio as a shortcut test for heterogeneity of variance. Biometrika 37:308-312.
Hatch, S.L. and R.H. White. 2004. Zoysiagrass, p. 1094-1100. In: L.E. Moser, B.L. Burson, and L.E. Sollenberger (eds.). Warm-season (C4) grasses. Monogr. No. 45. Amer. Soc. Agron., Crop Sci. Soc. Amer., Soil Sci. Soc. Amer., Madison, WI.

Huang, B. 1999. Water relations and root activities of Buchloe dactyloides and Zoysia japonica in response to localized soil drying. Plant Soil 208:179-186.

Huang, B.R. and H.W. Gao. 1999. Physiological responses of diverse tall fescue cultivars to drought stress. HortScience 34:897-901.

Kim, K.S. and J.B. Beard. 1988. Comparative turfgrass evapotranspiration rates and associated plant morphological characteristics. Crop Sci. 28:328-331.

Kopec, D.M., R.C. Shearman, and T.P. Riordan. 1988. Evapotranspiration of tall fescue turf. HortScience 23:300-301.

Marcum, K.B., M.C. Engelke, S.J. Morton, and R.H. White. 1995. Rooting characteristics and associated drought resistance of zoysiagrasses. Agron. J. 87:534-538.

Meyer, J.L. and V.A. Gibeault. 1986. Turfgrass performance under reduced irrigation. Calif. Agr. 40(7/8):19-20.

Morris, K.N. 1996. National buffalograss test-1991. NTEP Final Rpt. No. 96-14. National Turfgrass Evaluation Program, U.S. Dept. Agr, Agr. Res. Serv., Beltsville, MD

National Turfgrass Evaluation Program. 2006. 2002 National bermudagrass test. 2003-2006 Data. Final Rpt. NTEP No. 07-10. 5 July 2009. <http://www.ntep. org/reports/bg02/bg02_07-10f/ bg02_07-10f.htm>.

Qian, Y. and M.C. Engelke. 1999. Performance of five turfgrasses under linear gradient irrigation. HortScience 34:893-896.

Qian, Y.L. and J.D. Fry. 1997. Water relations and drought tolerance of four turfgrasses. J. Amer. Soc. Hort. Sci. 122:129-133.

Qian, Y.L., J.D. Fry, and W.S. Upham. 1996. Rooting and drought avoidance of warm-season turfgrasses and tall fescue in Kansas. Crop Sci. 37:905-910.

Riordan, T.P., S.A. deShazer, J.M. JohnsonCicalese, and R.C. Shearman. 1993. An overview of breeding and development of buffalograss. Intl. Turfgrass Soc. Res. J. 7:816-822.

Schmidt, R.E. 1973. Drought stress on turf. U.S. Golf Assn. Green Section Record 11 15$): 7-10$.

Severmutlu, S., N. Mutlu, R.C. Shearman, E. Gurbuz, O. Gulsen, M. Hocagil, O. 


\section{Research Reports}

Karaguzel, T. Heng-Moss, T.P. Riordan, and R.E. Gaussoin. 2011. Establishment and turf qualities of warm-season turfgrasses in the mediterranean region. HortTechnology 21:67-81.

Severmutlu, S., T.P. Riordan, and R.C. Shearman. 2005. Registration of 'Cody' buffalograss. Crop Sci. 45:2122-2123.

Shearman, R.C. 1986. Kentucky bluegrass cultivar evapotranspiration rates. HortScience 21:455-457.

Shearman, R.C. 1989. Perennial ryegrass cultivar evapotranspiration rates. HortScience 24:767-769.
Short, D.C. and T.D. Colmer. 2007. Development and use of a variable-speed lateral boom irrigation system to define water requirements of 11 turfgrass genotypes under field conditions. Aust. J. Exp. Agr. 47:86-95

Sifers, I.S. and J.B. Beard. 1999. Drought resistance in warm-season grasses. Golf Course Mgt. 67(9):67-70.

Tovey, R., J.S. Spencer, and D.C. Muckel. 1969. Turfgrass evapotranspiration. Agron. J. 61:863-867.

White, R.H., A.H. Bruneau, and T.J. Cowett. 1993. Drought resistance of diverse tall fescue cultivars, p. 607-613. In:
R.N. Carrow, N.E. Christians, and R.C. Shearman (eds.). Proc. 7 th Intl. Turfgrass Soc. Res. Conf. Intertec Publ., Overland Park, KS.

White, R.H., M.C. Engelke, S.J. Anderson, B.A. Ruemmele, K.B. Marcum, and G.R. Taylor. 2001. Zoysiagrass water relations. Crop Sci. 41:133-138.

Youngner, V.B., A.W. Marsh, R.A. Strohman, V.A. Gibeault, and S. Spaulding. 1981. Water use and quality of warm-season and coolseason turfgrass, p. 251-257. In: R.W. Sheard (ed.). Proc. 4th Intl. Turfgrass Res. Conf., Ontario Agr. College, Univ. of Guelph, Guelph, ON, Canada. 